\title{
Treatment of spinal cord injury with mesenchymal stem cells
}

\author{
Ling Ling Liau', Qi Hao Looi², Wui Chuen Chia², Thayaalini Subramaniam³ ${ }^{3}$ Min Hwei Ng${ }^{3}$ and Jia Xian Law $^{3^{*}}$ (D)
}

\begin{abstract}
Background: Spinal cord injury $(\mathrm{SCl})$ is the damage to the spinal cord that can lead to temporary or permanent loss of function due to injury to the nerve. The SCI patients are often associated with poor quality of life.

Results: This review discusses the current status of mesenchymal stem cell (MSC) therapy for SCl, criteria to considering for the application of MSC therapy and novel biological therapies that can be applied together with MSCS to enhance its efficacy. Bone marrow-derived MSCs (BMSCs), umbilical cord-derived MSCs (UC-MSCs) and adipose tissue-derived MSCS (ADSCs) have been trialed for the treatment of SCI. Application of MSCs may minimize secondary injury to the spinal cord and protect the neural elements that survived the initial mechanical insult by suppressing the inflammation. Additionally, MSCs have been shown to differentiate into neuron-like cells and stimulate neural stem cell proliferation to rebuild the damaged nerve tissue.

Conclusion: These characteristics are crucial for the restoration of spinal cord function upon SCl as damaged cord has limited regenerative capacity and it is also something that cannot be achieved by pharmacological and physiotherapy interventions. New biological therapies including stem cell secretome therapy, immunotherapy and scaffolds can be combined with MSC therapy to enhance its therapeutic effects.
\end{abstract}

Keywords: Spinal cord injury, Stem cell therapy, Mesenchymal stem cells, Nerve regeneration

\section{Background}

The spinal cord connects most of the periphery nervous system to the brain and is protected by a vertebral column that is divided into multiple segments. These segments are grouped into 4 major regions, $\mathrm{C} 1-\mathrm{C} 8$ cervical, T1-T12 thoracic, L1-L5 lumbar and S1-S5 sacral vertebrae. Spinal nerves protruded from different segments of vertebral column innervate different body regions. The cervical nerves control the motor and sensory functions of the head, neck, shoulder, arm and hand. The thoracic nerves control the motor and sensory functions of the chest and abdominal walls. The lumbar nerves innervate

\footnotetext{
*Correspondence: danieljx08@gmail.com; lawjx@ppukm.ukm.edu.my

${ }^{3}$ Centre for Tissue Engineering and Regenerative Medicine, Faculty

of Medicine, Universiti Kebangsaan Malaysia Medical Centre, JalanYaacob Latif, Bandar Tun Razak, 56000 Kuala Lumpur, Malaysia

Full list of author information is available at the end of the article
}

the hip and leg and the sacral nerves supply the genitals and lower digestive tract. Within the vertebral column, the spinal cord is covered and protected by the meninges (dura mater, arachnoid mater and pia mater) and cerebrospinal fluid (in subarachnoid space between the arachnoid and pia mater) [1-3]. Apart from serving as a conduit for the transmission of sensory input to the brain and motor output to the effector tissues, the spinal cord is also responsible for the production of spinal reflex that protects the body from harmful stimuli [4].

A spinal cord injury (SCI) is damage to the spinal cord that can lead to temporary or permanent changes to the cord's normal motor, sensory and autonomic function, resulting in calamitous neurological deficiency and disability [5]. The prevalence and incidence of SCI are ranging from 8 to 906 cases per million people according to the countries and regions and is more common in males below 30 years old [6]. SCI can affect most of the bodily

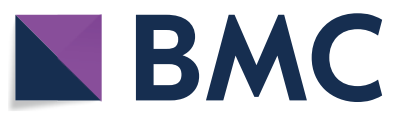

c) The Author(s) 2020. This article is licensed under a Creative Commons Attribution 4.0 International License, which permits use, sharing, adaptation, distribution and reproduction in any medium or format, as long as you give appropriate credit to the original author(s) and the source, provide a link to the Creative Commons licence, and indicate if changes were made. The images or other third party material in this article are included in the article's Creative Commons licence, unless indicated otherwise in a credit line to the material. If material is not included in the article's Creative Commons licence and your intended use is not permitted by statutory regulation or exceeds the permitted use, you will need to obtain permission directly from the copyright holder. To view a copy of this licence, visit http://creativeco mmons.org/licenses/by/4.0/. The Creative Commons Public Domain Dedication waiver (http://creativecommons.org/publicdomain/ zero/1.0/) applies to the data made available in this article, unless otherwise stated in a credit line to the data. 
functions including breathing, bowel and bladder function, hormone release, and sexual function, due to the loss of connection between the brain and the peripheral nervous system. Although the severity of SCI and resulting disability differ from individual to individual, nonetheless, it will significantly affect the patient quality of life. After injury, regeneration of spinal cord axons is very limited due to the low growth capacity of neurons, presence of inhibitory factors in central nervous system myelin, the formation of glial scar, and lack of neurotrophic factors and nerve growth factors [7, 8]. Conventional treatment of SCI focuses on stabilizing the injured area via surgery, preventing secondary injury through pharmacological intervention, and rehabilitation to prevent loss of function and to help regain the loss functions [9, 10]. However, these treatments have limited success as they cannot stimulate spinal cord regeneration.

Several types of stem cells have been tested or being tested clinically for the treatment of SCI, including MSCs, ESC-derived oligodendrocyte precursor cells, fetal-derived neural stem cells, and central nervous system stem cells [11]. Figure 1 shows the applications of stem cells in the treatment of SCI. Thus far, most of the trials used MSCs isolated from bone marrow (BMSCs), umbilical cord (UC-MSCs) and adipose tissue (ADSCs) to treat SCI. MSCs were used to treat SCI as the cells can suppress the inflammation to limit the secondary injury, secrete paracrine factors that protect the remaining axons and promote axonal regeneration, and differentiate into nerve cells to replace the damaged cells $[12,13]$. Both autologous and allogeneic MSCs have been used as the cells can evade rejection by the host immune system $[14,15]$.

In this review, we discussed the current status of MSC therapy for SCI focusing on the clinical trial results, the criteria to consider when applying the MSC therapy and the novel biological therapies that can be used together with MSC therapy to enhances its therapeutic potential.

\section{Spinal cord injury}

SCI is classified as tetraplegia and paraplegia depending on the spinal cord segment affected. Tetraplegia refers to the injury at the cervical segment that causes loss of bodily control below the neck while paraplegia involves damage to the thoracic segment and the segments below that may affect all or part of the trunk, pelvis and legs.

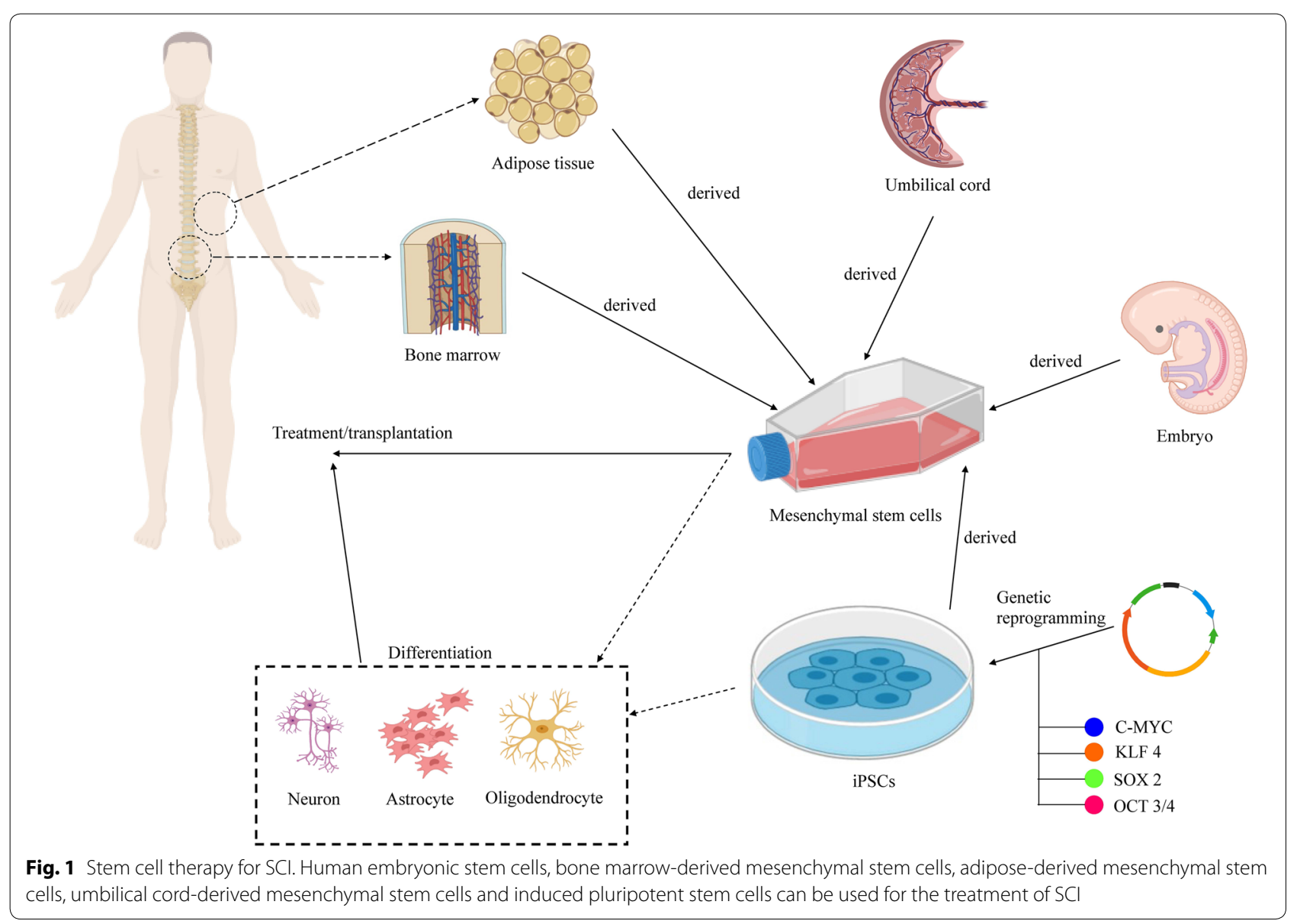


Paraplegics have full control of the arms and hands [16]. Based on the severity, SCI can be categorized as 'complete' if the control over the area below the affected area is loss totally and as 'incomplete' when some of the sensation, muscle function, and bodily functions are retained [17].

Traumatic SCI can be divided into 2 phases, i.e. irreversible primary injury that happens immediately at the moment of injury and secondary injury that kicks in within minutes after the primary injury [18]. Mechanical injury to the spinal cord will lead to disruption of blood-spinal cord barrier (BSCB), cord hemorrhage, swelling, ischemia, inflammation, loss of microvasculature, electrolyte shifts, free radical generation, lipid peroxidation and release of toxic compounds from damaged neurons and glial cells that trigger the progressive secondary injury (Fig. 2). The intense inflammation and toxin released at the injury site will trigger the apoptosis of neurons and glial cells. Besides, the proinflammatory cytokines and chemokines will stimulate the differentiation of neural stem/progenitor cells into astroglia, leading to the transition from the inflammation phase to scar formation [19]. Deposition of the extracellular matrix (ECM) components (e.g. glial fibrillary acidic protein
(GFAP), nestin and vimentin), and accumulation and activation of glial cells contribute to the formation of glial scar around the periphery of the lesion. Fibroblasts and Schwann cells will migrate to the center of the lesion and secrete the ECM proteins such as collagen, fibronectin and laminin, leading to fibrotic scarring. In the early phase, the formation of glial scar plays an important role in containing the injury area, limiting the inflammation, clearing the debris, regeneration of blood-brain barrier, preventing the spread of toxic compounds to the surrounding tissue and production of neurotrophins. However, at the later phase, glial scar and fibrotic scar, as well as the presence of axonal growth inhibitors, prevented the neuronal regeneration $[20,21]$. Besides, neurons in the spinal cord have low regeneration and proliferation potential.

Spinal cord damage can be reduced by preventing, attenuating and reversing secondary injury. Many studies look into interventions targeting secondary injury with the hope of preserving and improving spinal cord neurological functions [16, 22-24]. Pathophysiology of traumatic SCI has been excellently summarized by Ahuja et al. that divided traumatic SCI temporally into the acute (0-48 h), subacute (2-14 days), intermediate ( 2 weeks to

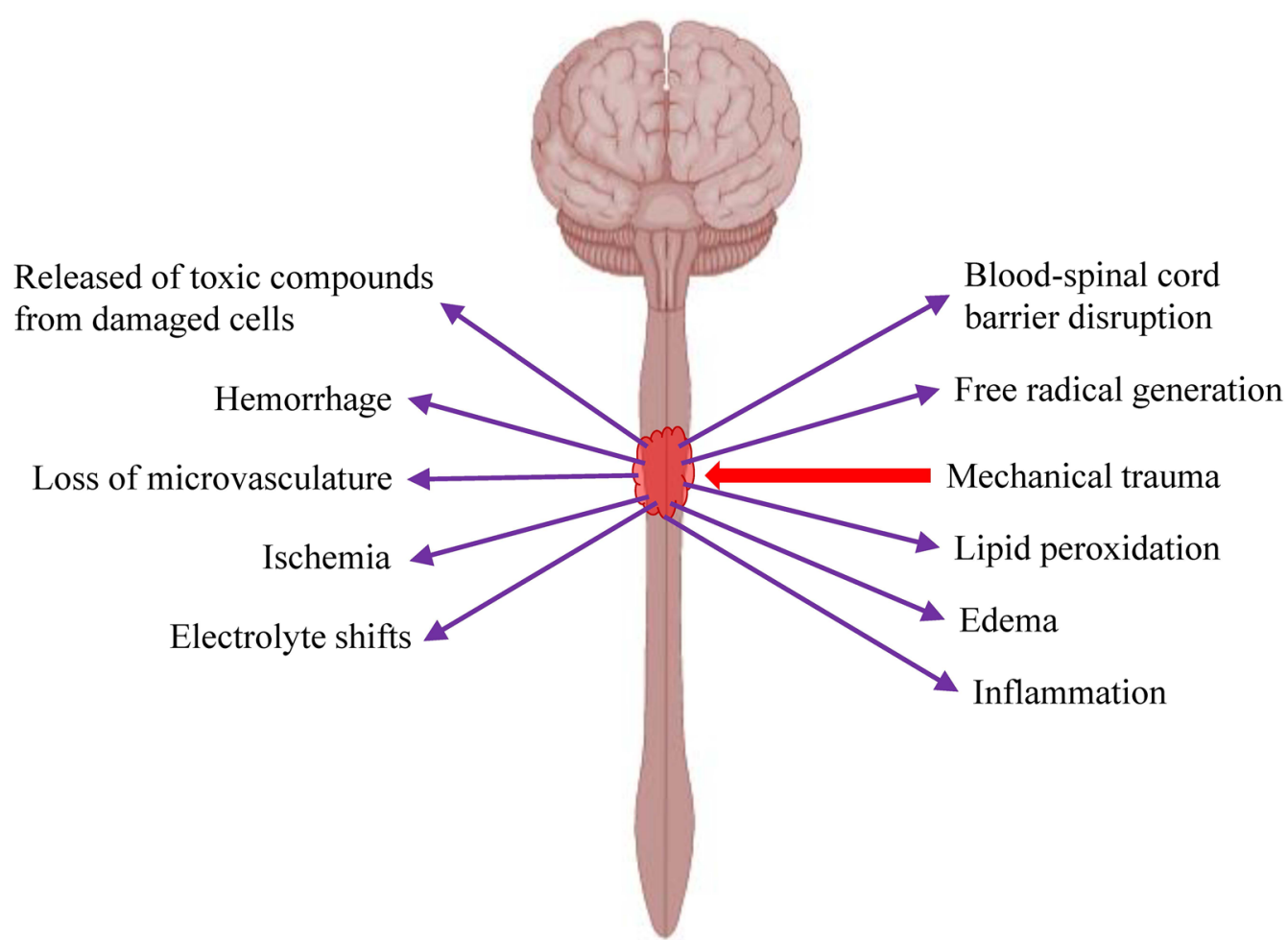

Fig. 2 Changes to the injured spinal cord at the molecular and cellular level. Mechanical trauma to the spinal cord will cause bleeding, oedema, disruption in blood supply, inflammation, disruption of blood-spinal cord barrier, electrolyte shifts, oxidative stress, lipid peroxidation, cell necrosis and release of toxic substances by the damaged cells 
6 months) and chronic ( $>6$ months) based on its pathophysiology [2]. Currently, ASIA (American Spinal Injury Association) Impairment Scale (AIS) is the gold standard used to classify SCI. AIS graded the SCI from A to $\mathrm{E}$ based on the sensory and motor function preserved. Table 1 indicates the classification of AIS grading [25].

\section{Mesenchymal stem cell therapy for spinal cord injury}

Traditionally, the regenerative capacity of MSCs was thought to be related to its plasticity to differentiate into neural and glial cells [26, 27]. However, recent studies suggested that the therapeutic effect is mostly exerted by their paracrine activity as MSCs have been found to secrete a broad range of bioactive molecules [28]. MSCs secrete VEGF, HGF, IGF-I, stanniocalcin-1, TGF- $\beta$, and GM-CSF that promote the survival of damaged neurons and oligodendrocytes [29, 30]. Together with PIGF, MCP1 , bFGF and IL-6, these factors also stimulate angiogenesis [31]. Proliferation and regeneration of the remaining neurons are stimulated by the GDNF, BDNF, and NGF secreted by the MSCs [32]. MSCs exert its immunomodulatory effects via cell-to-cell contact and secretion of IL-10, TGF- $\beta$, PGE-2, galectin-1, indolamine 2,3 dioxygenase (IDO) and HLA-G [30, 33-35]. By controlling the inflammation, MSCs reduce the damages done to the remaining and surrounding unaffected tissues. MSCs also can inhibit gliosis, thus improving the ECM environment for better neurite growth [36]. Besides, MSCs have antioxidant property and can stimulate cells to produce antioxidant enzymes [37, 38]. Apart from the paracrine factors, MSCs also have been reported to exert its therapeutic effect via direct cell fusion, mitochondrial transfer and production of microvesicles [39]. Figure 3 summarizes the mechanisms of action of MSC therapy.

\section{Bone marrow-derived mesenchymal stem cells}

BMSC is the most popular source of MSCs for the treatment of SCI with more than 20 clinical trials registered on the ClinicalTrials.gov database. Generally, none of the studies was able to improve the neurological function of all the recruited patients. The key findings of these clinical trials are summarized in Table 2.
Most of the studies administered BMSCs intrathecally to the patients. Jeon et al. performed a phase I trial that administered BMSCs into the intramedullary space $\left(8 \times 10^{6}\right.$ cells $)$ and intradural space $\left(4 \times 10^{7}\right.$ cells $)$ of 10 patients at 1 month to 108 months post-SCI and more cells $\left(5 \times 10^{7}\right.$ cells $)$ were administered at 4 weeks and 8 weeks after the first cell transplantation through lumbar tapping [40]. It was found that the patients ASIA score, electromyography (EMG) and somatosensory evoked potential (SEP) improved after the treatment. Long-term follow-up of the patients showed that 3 patients with AIS grade B have better motor power of the upper extremities and activities of daily living as well as electrophysiological improvement. MRI demonstrated a reduction in lesion size and presence of fiber-like low signal intensity streaks [41]. The subsequent phase III trial was conducted with a modified protocol that doubled the number of cells administered into the intramedullary space $\left(1.6 \times 10^{7}\right.$ cells $)$, slightly reduced the amount of cell transplanted into the intradural space $\left(3.2 \times 10^{7}\right.$ cells $)$ and removed the second and third MSC transplantation at 4 weeks and 8 weeks [42]. Unfortunately, the study was prematurely terminated due to unexpected poor results whereby only 2 out of 16 patients showed improvement in motor power of the upper extremities. In another trial, Saito et al. [43] reported minimal improvement in the 3 patients with AIS grade A but significant improvement was observed in the 2 patients with AIS grade B and C after BMSC therapy. El-Kheir et al. [44] recorded an improvement in AIS grade in 17/50 patients treated with BMSCs and physiotherapy while none of the 20 patients treated with physiotherapy alone demonstrated AIS grade conversion. Karamouzine et al. [45] administered BMSCs into 11 patients with AIS grade A and found that $5 / 11$ patients have their AIS grade improved to $C$, which is much better than the $3 / 20$ recorded in the control group. Pal et al. [46] treated 30 patients with BMSCs but did not found conversion in AIS grade in any of the patients. Besides, there were also no significant changes in SEP, motor evoked potentials (MEP) and nerve conduction velocity $(\mathrm{NCV})$ as well as a variable pattern of recovery in Barthel Index. Vaquero et al. [47] reported improvement in sensation, motor and bladder function,

\section{Table 1 Classification of AIS grading}

\begin{tabular}{ll}
\hline Grade & Characterizations \\
\hline A & Complete loss of control of the body areas by the lowest sacral nerves \\
B & Retention of feeling but not movement below the level of injury \\
C & More than half the key muscles below the level of injury can move, but not against the gravity \\
D & More than half of the muscle below the level of injury can move against the gravity \\
E & Normal sensory and motor function for patient with history of SCl \\
\hline
\end{tabular}




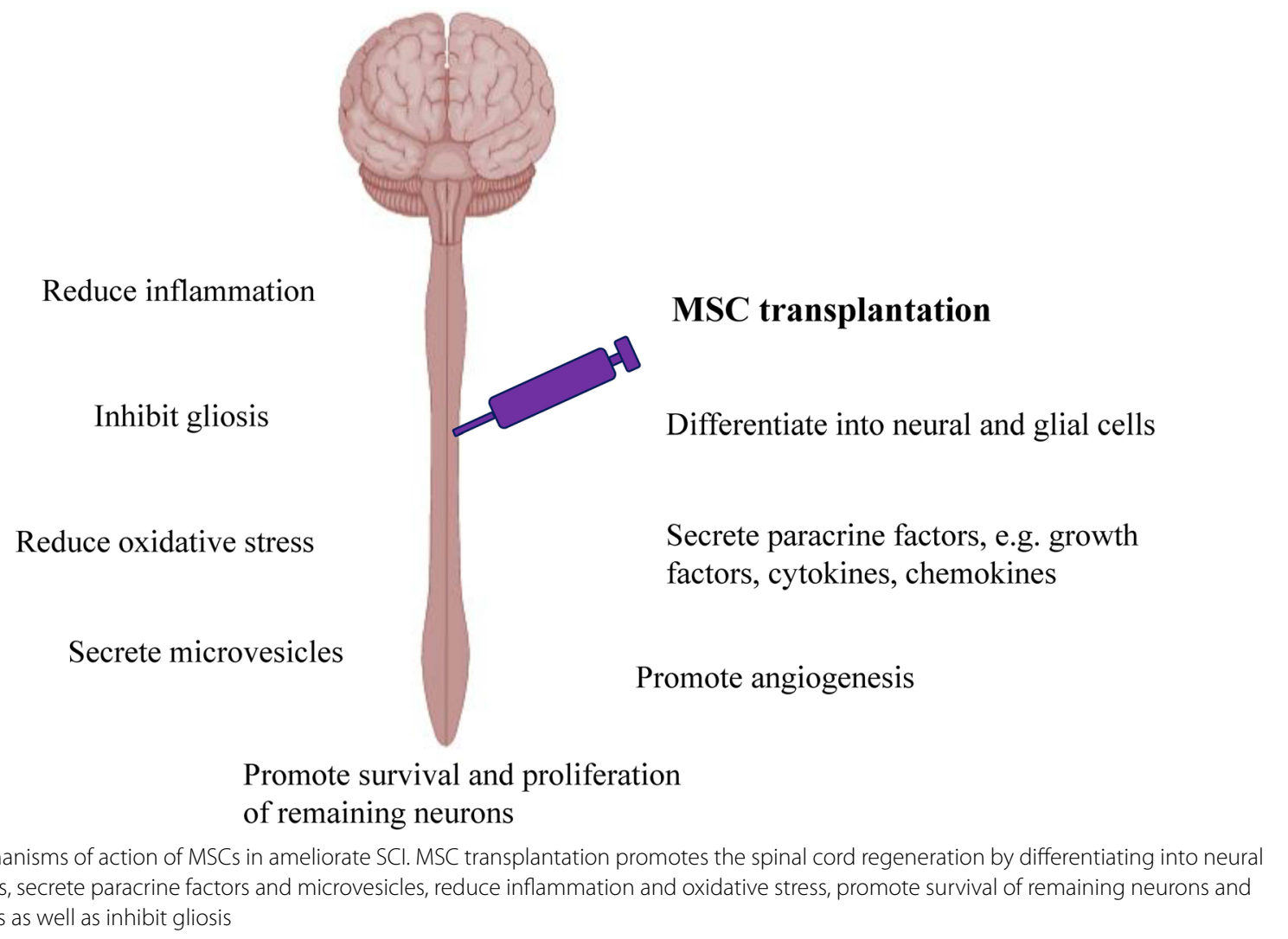

and IANR-SCIFRS score as well as a reduction in neuropathic pain in the chronic SCI patients (time of injury to participation $13.65 \pm 14.79$ years) received the BMSC therapy.

Several studies reported improvement in AIS grade in the chronic SCI patients that received the BMSCs through the intraspinal route. Mendonca et al. [48] found improvement in AIS grade from A to B in 6/12 patients and from $A$ to $C$ in one patient. Similarly, Dai et al. [49] found that BMSC treatment improved the AIS grade of $9 / 20$ SCI patients from A to B while none of the 20 patients in the control group showed conversion in AIS grade. Jiang et al. [50] found that $8 / 8$ (100\%) patients with AIS grade $\mathrm{C}$ showed improvement in AIS grade after BMSC therapy compared to $3 / 4$ (75\%) and $4 / 8$ (50\%) patients with AIS grade B and A, respectively.

Apart from BMSCs, several studies applied the bone marrow mononuclear cells (BMMCs) and bone marrow nucleated cells (BMNCs) to treat SCI. Syková et al. treated $20 \mathrm{SCI}$ patients with BMMCs and found that $5 / 6$ patients received the cells close to the lesion site (through arteria vertebralis) showed improvement in ASIA score compared to only $1 / 14$ patients that demonstrated ASIA score improvement after received the cells intravenously [51]. Besides, the authors also reported the benefit (improvement in ASIA score) of applying the cells during the subacute phase compared to the chronic phase. Geffner et al. [52] administered BMMCs through the intraspinal, intrathecal and intravenous routes to the same patients and reported improvement in AIS grade in $6 / 8$ patients. Jarocha et al. [53] reported the transplantation of BMNCs at 10 weeks after SCI and subsequent transplantation of autologous BMSCs every 3-4 months for 5 times on a 15 years old patient with AIS grade A. On 2-year follow-up, the AIS grade improved to C/D (score increased from 112 to 231). Encouragingly, the patient's control of body trunk, bladder filling sensation, bladder control, and anal sensation was restored, and muscle strength in lower extremities improved from plegia to deep paresis. Moreover, the patient regained the ability to stand and walk with support. Sharma et al. [54] transplanted BMNCs to 56 patients with chronic SCI (mean duration of injury 64 months) and found that 4 patients showed improvement in AIS grade and 24 patients have improved Functional Independence Measure (FIM) score. 


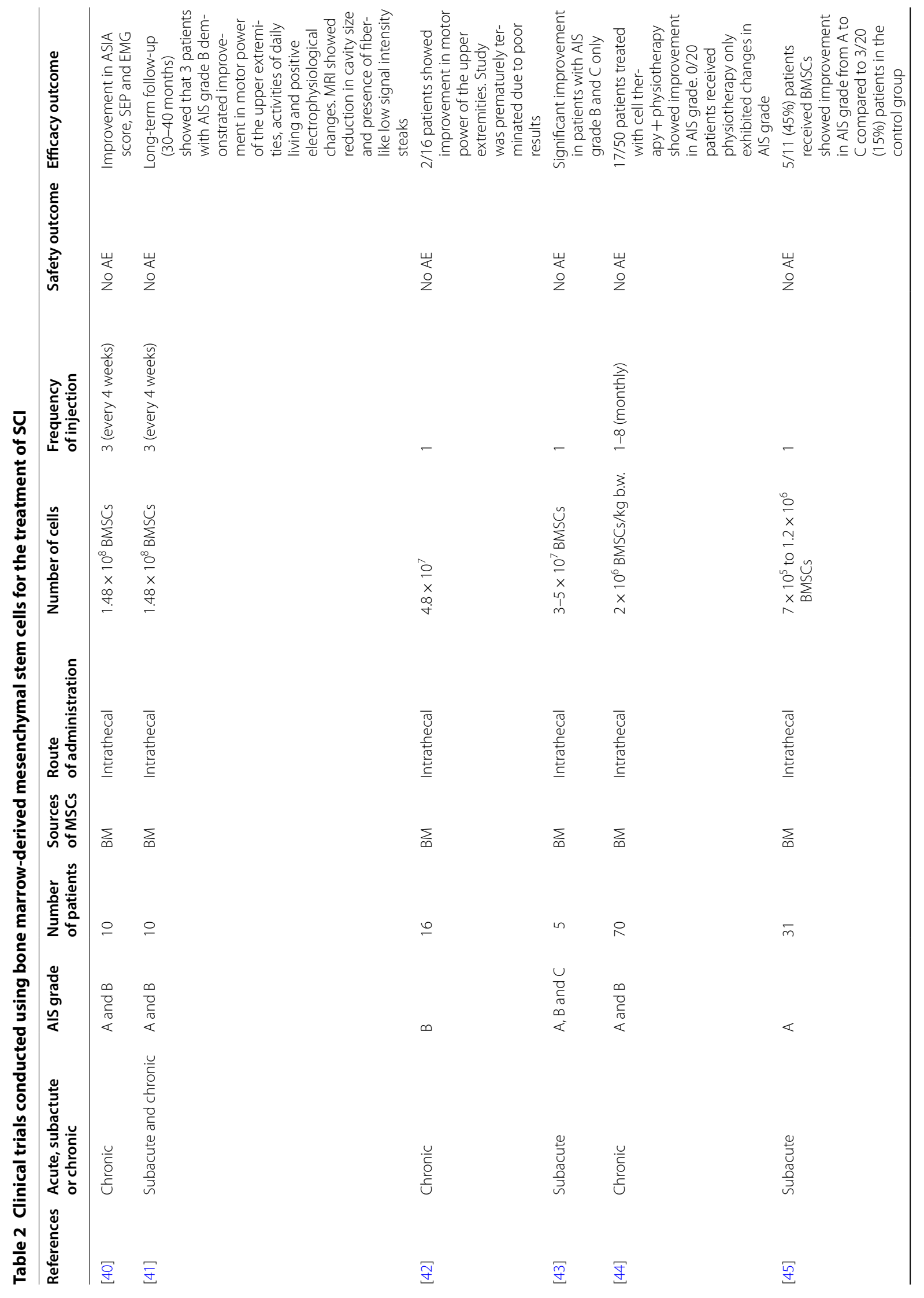




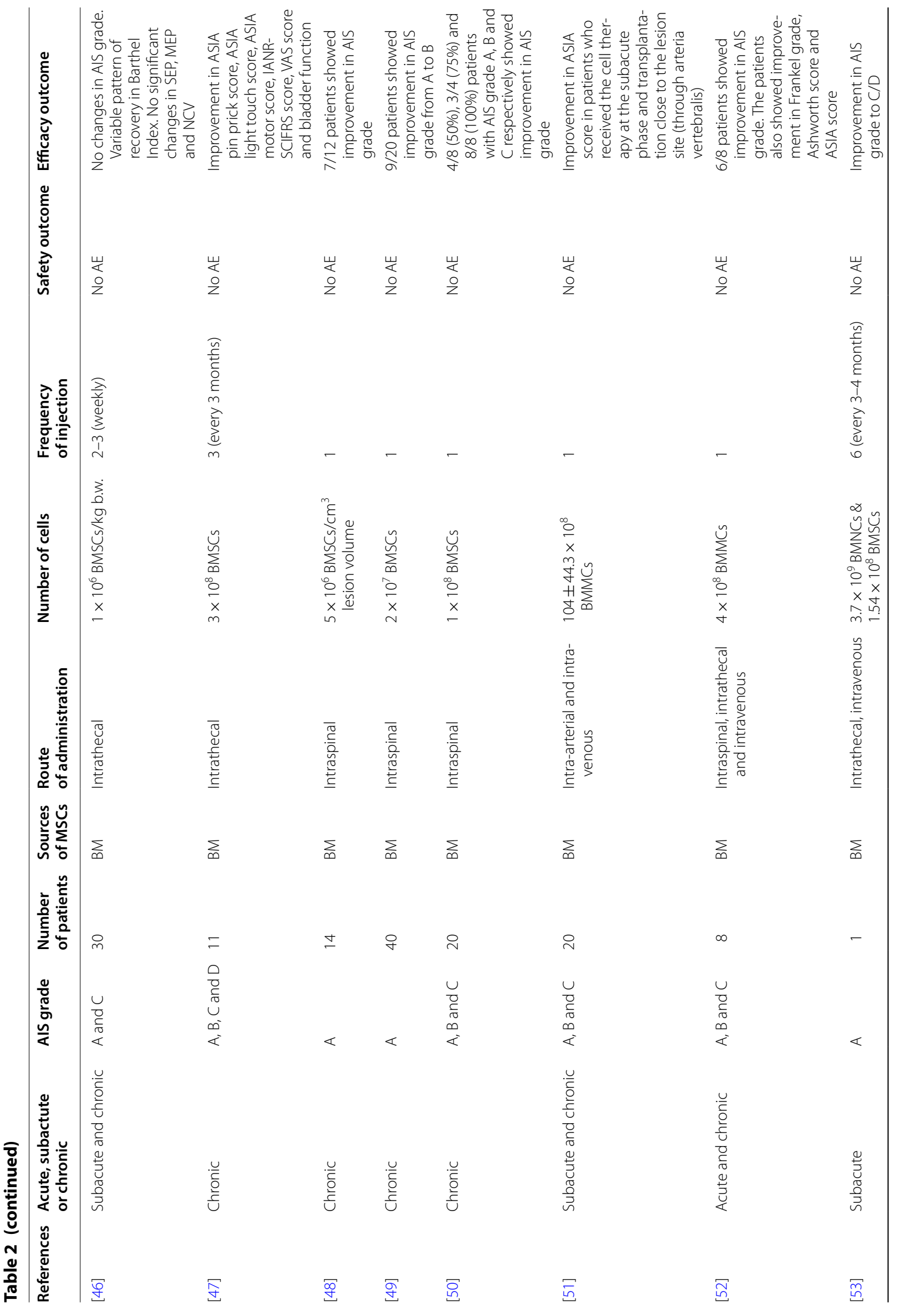




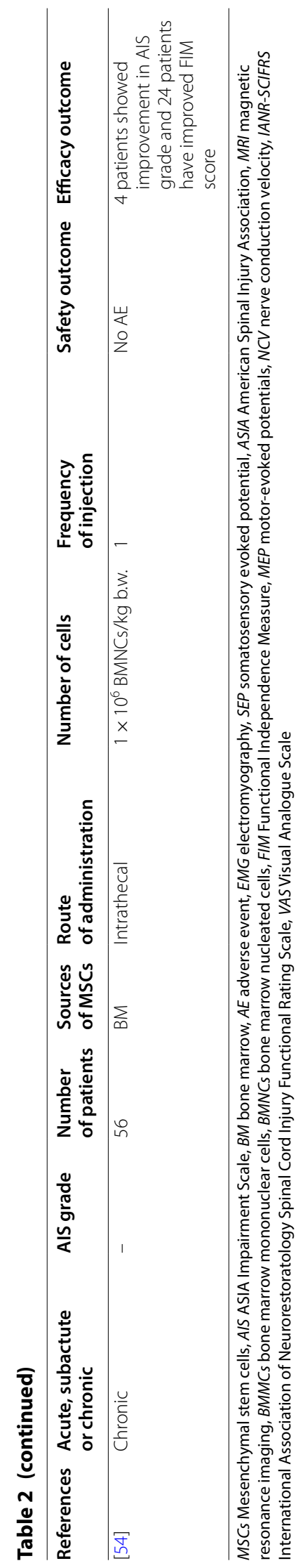


Umbilical cord-derived mesenchymal stem cells

UC-MSCs were used for the treatment of SCI due to its ease of sourcing, excellent in vitro expansion capacity, fast proliferation and low immunogenicity. UC-MSCs have low expression of HLA-ABC and no expression of HLA-DR and co-stimulatory antigens such as CD40, CD80, and CD86 that are associated with immune rejection $[33,55]$. Additionally, UC-MSCs have more robust growth and more potent immune suppression property compared to BMSCs. Similar to BMSCs, UC-MSCs can be differentiated into multiple cell types, including the neural-like and glial-like cells [56-59]. The collection of UC-MSCs is noninvasive and its usage has not been encumbered with ethical issues as the cells are derived from redundant tissues and cause no harm to the donor. Although UC-MSCs are allogeneic, these cells utilize several mechanisms, including low expression of alloantigen, modulation of dendritic cell and $\mathrm{T}$ cell functions, and induction of regulatory $\mathrm{T}$-cells to avoid immune rejection [60]. Table 3 shows the clinical trials conducted using UC-MSCs for the treatment of SCI. Liu et al. [7] reported the treatment of $22 \mathrm{SCI}$ patients (time of injury to participation 2-204 months) with UC-MSCs and found that $13 / 22$ patients showed improvement in ASIA score and IANR-SCIFRS score. However, this was only limited to the patients with incomplete $\mathrm{SCI}$ as none of the 6 patients with complete SCI showed improvement. They concluded that intrathecal injection of UCMSCs can improve the neurologic function of chronic phase SCI patients with incomplete injury but not those with complete SCI. Cheng et al. [61] injected UC-MSCs intraspinally to 34 chronic phase SCI patients (time from injury to participation 12-72 months) with AIS grade A. They found that $7 / 10$ patients received cell therapy demonstrated improvement in sensation, motion, muscle tension and self-care ability, whereas only $5 / 14$ patients in the rehabilitation group and $0 / 10$ patients in the untreated control group showed improvement. Besides, the UC-MSC treated patients also showed significant improvement in maximum bladder capacity and maximum detrusor pressure. In contrast, all the urodynamic indicators deteriorated among the patients in the rehabilitation group. The contradicting results between these 2 studies regarding the efficacy of UC-MSCs in amelioration of complete SCI may be due to the different route of cell transplantation as Liu et al. and Cheng et al. used intrathecal and intraspinal injection, respectively (Table 4).

\section{Adipose tissue-derived mesenchymal stem cells}

Adipose tissue is ubiquitously available, can be easily collected using minimally invasive techniques such as subcutaneous lipoaspiration and contains a greater population of somatic stem cells compared to bone marrow [62, 63]. All these features render adipose tissue an ideal source of MSCs. Safety and efficacy of ADSC therapy in ameliorating SCI have been evaluated in a few human trials. Hur et al. [64] investigated the effect of intrathecal transplantation of autologous ADSCs in 14 patients with SCI. The result showed that 10 patients exhibited sensory improvement, 5 patients exhibited motor function improvement and 2 patients have improved voluntary anal contraction. However, MRI examination indicated that the lesion size remained unchanged. In a recent paper, Bydon et al. [65] reported the treatment of a SCI patient with 100 million autologous ADSCs. The cells were administered intrathecally. The patient showed improvement in ASIA motor and sensory score as well as improvement in the quality of life as indicated by the higher Global Health Score.

\section{Criteria to consider when applying mesenchymal stem cell therapy}

Based on the results reported in the clinical trials, MSC therapy is beneficial for SCI patients. However, not all the patients responded to the therapy and the improvement varied from patient to patient. These discrepancies can be due to patient variation, as they may have different severity of injury (AIS grade A to D), level of cord injury (cervical, thoracic, lumbar and sacral) and mechanism of primary injury (impact + transient compression, impact + persistent compression and laceration/transection). Apart from patient factors, variation in the MSC therapy such as cell source (allogeneic and autologous; bone marrow, umbilical cord and adipose tissue), route of cell administration (intrathecal, intraspinal and intravenous), timing of cell administration (acute, subacute and chronic phase), number of cell administration (single and multiple), number of cells administered (a few million to several hundred million) and cell preparation methods (BMSCs and BMMCs) also will affect the efficacy of the therapy (Fig. 4).

Both autologous and allogeneic MSCs can be used to treat SCI as the cells are immunoevasive. However, experiments on animal SCI models suggested that autologous MSCs are more effective compared to the allogeneic MSCs in treating SCI. ADSCs in the form of stromal vascular fraction (SVF) has been transplanted intraspinally to a SCI mouse model and the results showed that treatment with autologous SVF significantly improved the locomotor score compared to treatment with allogeneic SVF [66]. Besides, less demyelination and more integral structure were seen in spinal cord treated with autologous SVF. Similarly, autologous BMSCs transplanted intrathecally in a canine model were found to be more effective compared to allogeneic BMSCs in 
Table 3 Clinical trials conducted using umbilical cord-derived mesenchymal stem cells for the treatment of SCI

\begin{tabular}{|c|c|c|c|c|c|c|c|c|c|}
\hline References & $\begin{array}{l}\text { Acute, } \\
\text { subactute } \\
\text { or chronic }\end{array}$ & AIS grade & $\begin{array}{l}\text { Number } \\
\text { of patients }\end{array}$ & $\begin{array}{l}\text { Sources } \\
\text { of MSCs }\end{array}$ & $\begin{array}{l}\text { Route } \\
\text { of administration }\end{array}$ & $\begin{array}{l}\text { Number } \\
\text { of cells }\end{array}$ & $\begin{array}{l}\text { Frequency } \\
\text { of injection }\end{array}$ & $\begin{array}{l}\text { Safety } \\
\text { outcome }\end{array}$ & $\begin{array}{l}\text { Efficacy } \\
\text { outcome }\end{array}$ \\
\hline$[7]$ & Chronic & - & 22 & UC & Intrathecal & $\begin{array}{l}1 \times 10^{6} \text { UC- } \\
\text { MSCs/kg } \\
\text { b.w. }\end{array}$ & $\begin{array}{l}\text { Weekly } 4 \\
\text { times as } \\
\text { a course } \\
(17,4 \text { and } \\
1 \text { patients } \\
\text { received } \\
1,2 \text { and } \\
3 \text { courses } \\
\text { respec- } \\
\text { tively) }\end{array}$ & No AE & $\begin{array}{l}\text { 13/16 patients } \\
\text { with } \\
\text { incomplete } \\
\text { SCI showed } \\
\text { improve- } \\
\text { ment in } \\
\text { ASIA and } \\
\text { IANR-SCIFRS } \\
\text { score. 0/6 } \\
\text { patients with } \\
\text { complete } \\
\text { SCI showed } \\
\text { improve- } \\
\text { ment }\end{array}$ \\
\hline$[61]$ & Chronic & A & 34 & UC & Intraspinal & $\begin{array}{l}4 \times 10^{7} \text { UC- } \\
\text { MSCS }\end{array}$ & $\begin{array}{l}2 \text { (separate by } \\
10 \text { days) }\end{array}$ & No AE & $\begin{array}{l}\text { 7/10 (70\%), } \\
\text { 5/14 (36\%) } \\
\text { and 0/10 } \\
\text { (0\%) patients } \\
\text { in the UC- } \\
\text { MSC, reha- } \\
\text { bilitation and } \\
\text { untreated } \\
\text { control } \\
\text { group } \\
\text { showed } \\
\text { improve- } \\
\text { ment in } \\
\text { ASIA score, } \\
\text { Barthel Index } \\
\text { and muscle } \\
\text { tension }\end{array}$ \\
\hline
\end{tabular}

MSCs Mesenchymal stem cells, AIS ASIA Impairment Scale, UC umbilical cord, ASIA American Spinal Injury Association, IANR-SCIFRS International Association of Neurorestoratology Spinal Cord Injury Functional Rating Scale, $A E$ adverse event

ameliorating SCI as indicated by the higher Olby score and smaller cystic cavity in the histological analysis [67]. The poorer efficacy of allogeneic MSCs is likely due to the more rapid clearance of the cells compared to the autologous counterpart.

MSCs from various tissue sources, including bone marrow, umbilical cord and adipose tissue, have been tested clinically for the treatment of SCI. However, none of the clinical studies compared the MSCs from different tissue sources. A previous study compared the efficacy of ADSCs and BMSCs in treating SCI using a mouse model found that both MSCs are equally potent in improving the animal motor function [68]. However, ADSCs have higher survival rate upon transplantation. More studies need to be conducted in future to determine the best source of MSCs to treat SCI. Table 5 shows the comparison between BMSCs, ADSCs and UC-MSCs for the treatment of SCI.

MSCs have been administered via the intraspinal, intrathecal and intravenous route to the SCI patients (Fig. 5). The intraspinal route involves the direct transplantation of cells to the spinal cord, either directly on the lesion or at the periphery, while the intrathecal route involves the administration of cells into the subarachnoid space of the spinal cord. For the intravenous route, it is postulated that the transplanted MSCs will migrate across the BSCB to the spinal cord, attracted by the chemotactic factors at the lesion [69]. Most of the clinical studies administered the cells intraspinally and intrathecally because of the low migration of intravenously transplanted cells to the lesion [70]. Majority of the cells transplanted intravenously are trapped in the lung and other organs and only a small fraction of the transplanted cells will migrate to the lesion. Thus, a higher cell number is needed when the cells are administered intravenously. Syková et al. [51] reported improvement in ASIA score in 5/6 patients who received BMMCs near to the lesion (via the arteria vertebralis) while only $1 / 14$ patients who got the cells intravenously showed improvement.

MSC transplantation can be performed during the acute, subacute (or intermediate) and chronic phase of 
Table 4 Clinical trials conducted using adipose-derived mesenchymal stem cells for the treatment of SCI

\begin{tabular}{|c|c|c|c|c|c|c|c|c|c|}
\hline References & $\begin{array}{l}\text { Acute, } \\
\text { subactute } \\
\text { or chronic }\end{array}$ & AIS grade & $\begin{array}{l}\text { Number } \\
\text { of patients }\end{array}$ & $\begin{array}{l}\text { Sources } \\
\text { of MSCs }\end{array}$ & $\begin{array}{l}\text { Route } \\
\text { of administration }\end{array}$ & $\begin{array}{l}\text { Number } \\
\text { of cells }\end{array}$ & $\begin{array}{l}\text { Frequency } \\
\text { of injection }\end{array}$ & $\begin{array}{l}\text { Safety } \\
\text { outcome }\end{array}$ & $\begin{array}{l}\text { Efficacy } \\
\text { outcome }\end{array}$ \\
\hline$[64]$ & Chronic & $A, B$ and $D$ & 14 & AT & Intrathecal & $\begin{array}{l}9 \times 10^{7} \\
\text { ADSCs }\end{array}$ & 3 (monthly) & No AE & $\begin{array}{l}10 \text { patients } \\
\text { have } \\
\text { improved } \\
\text { ASIA sen- } \\
\text { sory score, } \\
5 \text { patients } \\
\text { have } \\
\text { improved } \\
\text { ASIA motor } \\
\text { score and } \\
2 \text { patients } \\
\text { have } \\
\text { improved } \\
\text { voluntary } \\
\text { anal con- } \\
\text { traction }\end{array}$ \\
\hline$[65]$ & Chronic & A & 1 & AT & Intrathecal & $\begin{array}{l}1 \times 10^{8} \\
\text { ADSCs }\end{array}$ & 1 & No AE & $\begin{array}{l}\text { The patient } \\
\text { showed } \\
\text { improve- } \\
\text { ment in } \\
\text { ASIA motor } \\
\text { and sen- } \\
\text { sory score } \\
\text { as well as } \\
\text { better qual- } \\
\text { ity of life as } \\
\text { indicated } \\
\text { by the } \\
\text { higher } \\
\text { Global } \\
\text { Health } \\
\text { Score. }\end{array}$ \\
\hline
\end{tabular}

SCI. Most clinicians consider the subacute phase as the optimal period for MSC therapy because the inflammatory process in acute phase will harm the injected cells while glial scar formed at the chronic stage inhibits axonal regeneration [71, 72]. A clinical study had shown that SCI patients who received MSC therapy during the subacute phase acquired greater improvement in ASIA score compared to those treated during the chronic phase [51].

Ideally, a single administration of MSCs is sufficient to exert its regenerative effect. However, a significant number of clinical studies administered the cells multiple times to get positive results [7, 40, 41, 44, 46, 47, 53, 61, 64]. It is postulated that the transplanted cells only can survive for a limited period in the hostile environment. Thus, extra injection is needed to deliver viable cells that can modulate the wound environment to favor regeneration. Worth mentioning is the study by a Korean group that found that reduction of MSC administration from 3 times in the preliminary study to 1 time in the phase III trial, despite increasing the number of cells transplanted, resulted in poorer therapeutic effect [41, 42]. Similarly, there is no consensus on the ideal number of cells for the treatment of SCI. In the clinical studies, the number of MSCs transplanted ranged from $7 \times 10^{5}$ to $10.4 \times 10^{9}$ cells $[45,51]$. More studies are needed in future to determine if multiple infusions are beneficial for the treatment of SCI and to determine the ideal cell number to be transplanted.

Generally, MSC therapy appears to be more effective in patients with AIS grade B and C compared to those with AIS grade A $[41,43,50]$. One of the mechanisms of action of MSCs is via the secretion of paracrine factors which promote the survival and proliferation of remaining neurons. However, in the more severe AIS grade $\mathrm{A}$, the number of preserved neurons is likely to be lower. Thus, it leads to poorer regeneration after MSC transplantation. In the future, more clinical trials with larger sample size are needed to support these findings and more preclinical studies are necessary to elucidate the mechanism involved. 


\section{Treatment factors}

Cell source- autologous and allogeneic; bone marrow, adipose tissue and umbilical cord

Route of cell administration- intraspinal, intrathecal and intravenous

Timing of cell administration- acute, subacute and chronic phase

Number of cell administrationsingle and multiple

Number of cell administered- hundred thousands to hundred millions

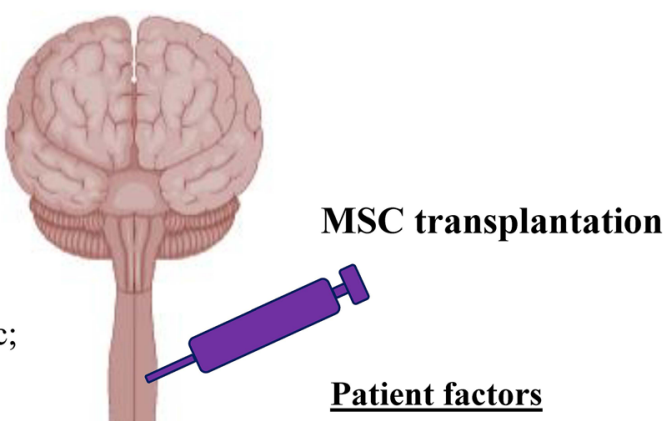

Severity of injury- AIS grade A to D

Level of cord injury- cervical, thoracic, lumbar and sacral

Mechanism of primary injury- impact

+ transient compression, impact +

persistent compression and

laceration/transection

Cell preparation method- ADSCs

and SVF; BMSCs and BMMCs

Fig. 4 Factors affect the efficacy of MSC therapy to treat SCI. These factors can be categorized as patients factors that include severity of the injury, level of cord injury and mechanism of primary injury as well as treatment factors such as cell source, route of cell administration, timing of cell administration, number of cell administration, number of cells administered and cell preparation method. ADSCs - adipose tissue-derived mesenchymal stem cells, SVF_-stromal vascular fraction, BMSCs—bone marrow-derived mesenchymal stem cells, BMMCs—bone marrow mononuclear cells, AIS—ASIA (American Spinal Injury Association) Impairment Scale

Table 5 Comparison between BMSCs, UC-MSCs and ADSCs for the treatment of SCI

\begin{tabular}{|c|c|c|c|}
\hline Characteristics & BMSCs & UC-MSCs & ADSCs \\
\hline Harvesting procedure & Invasive & None invasive & Invasive \\
\hline Easiness to isolate and culture & Easy & Easy & Easy \\
\hline Effect of age on cell quantity and quality & $\begin{array}{l}\text { Quantity and quality decline with } \\
\text { age }\end{array}$ & Unaffected & $\begin{array}{l}\text { Quantity } \\
\text { and qual- } \\
\text { ity decline } \\
\text { with age }\end{array}$ \\
\hline Potency to differential into nerve cells & Lower & Higher & Lower \\
\hline Cell renewal & Lower proliferative potential & Higher proliferative potential & $\begin{array}{l}\text { Lower pro- } \\
\text { liferative } \\
\text { potential }\end{array}$ \\
\hline Expression of embryonic markers & Lower & Higher & Lower \\
\hline Immune modulatory property & Good & Good & Good \\
\hline Allogeneic cell rejection & No & No & No \\
\hline Ethical issues & No & No & No \\
\hline Risk of tumorigenicity & Very low & Very low & Very low \\
\hline
\end{tabular}

The future of MSC therapy for spinal cord injury Clinical translation of MSC therapy in SCI progressed relatively slow despite encouraging results were reported in the preclinical studies on animal models. Currently, there is a lack of phase III trial exploring the therapeutic efficacy of MSC transplantation. This is caused by 


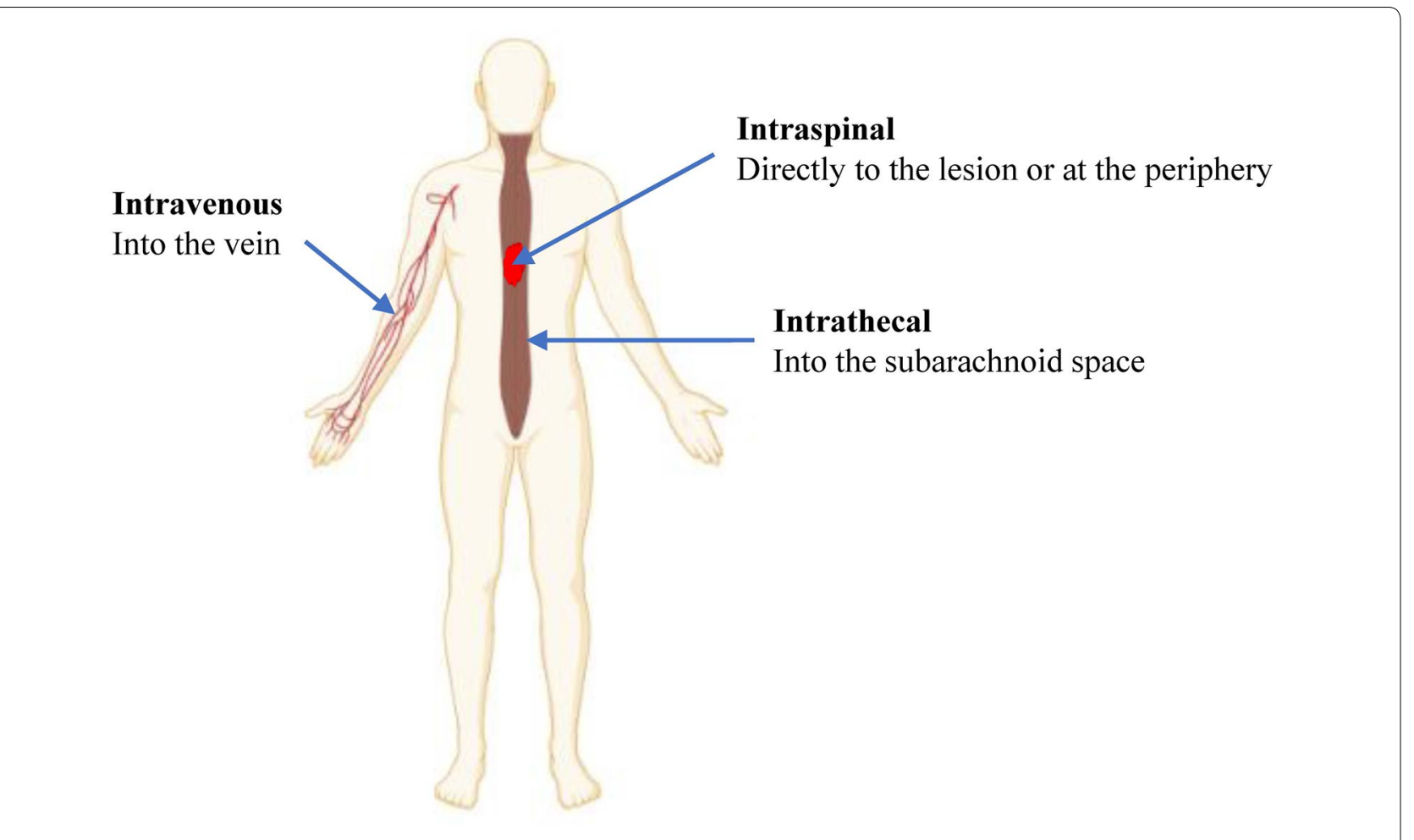

Fig. 5 Routes of MSC administration. MSCs have been transplanted to the SCI patients via the intravenous, intraspinal and intrathecal route

several reasons, including regulatory issues concerning the therapeutic application of MSCs, the high cost of phase III trial and low patient willingness to receive novel therapies without concrete evidence of clinical efficacy. Modest clinical efficacy and poor study design of the preliminary study also hindered the progression of MSC therapy. For example, a phase III study in Korea examining the effectiveness of BMSC therapy in 16 patients with chronic SCI reported that injection of $1.6 \times 10^{7}$ and $3.2 \times 10^{7}$ cells into the intramedullary and subdural space respectively resulted in poor therapeutic effect whereby only 2 patients showed neurological improvement [42]. The researchers of the aforementioned study used a different treatment protocol modified from the preliminary study due to regulatory requirements as multiple stem cell administration in phase III trial is typically prohibited by the authority [41]. Despite all the challenges, the future of MSC therapy for SCI remains bright as it has shown excellent efficacy in certain clinical studies.

\section{Novel biological therapies for spinal cord injury}

Several new therapeutic adjuncts and treatment strategies which include stem cell secretory product-based therapy, scaffold-based therapy and immunotherapy may be used together with MSC therapy to enhance the therapeutic efficacy of MSC by improving the cells survival, migration, engraftment and proliferation.

\section{Stem cell secretome therapy}

The application of MSCs to treat SCI showed encouraging result in both preclinical and clinical studies owing to its excellent immunomodulatory and regenerative capacities. However, the regenerative effects of stem cells do not solely rely on its differentiation potential and its ability to replace the damaged tissues, but also mediated by its secretome via the paracrine and autocrine mechanisms [73]. Stem cells derived-secretome is defined as the set of bioactive factors secreted to the extracellular space which comprise of soluble proteins, nucleic acids, lipids, cytokines, neurotrophins, growth factors and extracellular vesicles (EVs) [74]. Recently, there has been a paradigm shift from cellular therapy to secretome therapy due to several advantages of stem-cells derived secretomes, including its low tumorigenicity potential as secretomes do not endogenously replicate, scalable production, circulate for an extended period within the body, easily obtainable from the cell culture medium, modifiable bioactive content and can be stored without using toxic agents such as dimethyl sulfoxide (DMSO) $[75,76]$. Many in vitro and preclinical studies have shown that MSCs-derived secretomes exert immunomodulatory, 
neurotrophic/neuroprotective and angiogenetic effects in various SCI models to promote nerve regeneration [69, 77].

Among various components of secretomes, EVs, composing of microvesicles and exosomes are considered to be the most valuable therapeutic agent [74]. MSC-EVs administered intravenously and intranasally in rats with $\mathrm{SCI}$ were found to accumulate and incorporated into the neurons at the lesion site [78, 79]. MSCs-derived EVs have been demonstrated to promote angiogenesis, suppress inflammation, reduce the lesion size, prevent neuronal cells apoptosis, support neuronal cells survival and regeneration, improve the integrity of BSCB and prevent glial scar formation, eventually improve the neuronal and motor functions using the in vitro and in vivo models [80-83]. Besides, MSC-EVs were found to be neuroprotective by reducing the $\mathrm{A} 1$ astrocytes that are neurotoxic to the synapse, myelin sheath and neurons through inhibition of NFkB p65 subunit nuclear translocation [84]. In the same study, the authors also reported that MSC-EVs were on par with MSCs in ameliorating SCI. Motor function recovery in $\mathrm{SCI}$ is often associated with the integrity of BSCB as disruption of BSCB and insufficient pericytes could hinder the recovery of nerve tissues. Recently, $\mathrm{Lu}$ et al. [81] demonstrated that MSC-EV administration suppressed the migration of pericytes and improved the integrity of the BSCB via down-regulation of NF- $\mathrm{kB}$ p 65 signaling. Interestingly, EVs also could exert analgesic effects in a nerve injury-induced pain rat model apart from suppressing the inflammation and promoting the growth of neuronal cells [85].

Nowadays, EVs are also being explored as a biological vehicle to transfer bioactive factors to the damaged spinal cord. A previous study showed that miR-133b played a vital role in neuron differentiation and neurite outgrowth [86]. Hence, MSCs were modified to secrete miR-133brich EVs for the treatment of rats with SCI [87]. Treatment with miR-133b-rich EVs promoted the recovery of hindlimb locomotor function, reduced the lesion volume, protected the neuronal cells and enhanced axon regeneration compared to the EV and control groups. MSCsderived exosomes also have been modified to transfer miR-29b and miR-216a-5p to promote regeneration of injured spinal cord $[88,89]$. Interestingly, MSCs-derived exosomes also have been used to deliver phosphatase and tensin homology small interfering RNA (PTEN) that promote neuronal cell growth, support angiogenesis and suppressing gliosis when the exosomes were delivered intranasally to the rat SCI model [79].

There are several hurdles to overcome in the clinical application of secretomes/EVs. These obstacles include biodistribution of secretomes/EVs, persistency of secretome/EV biological content and unestablished regulatory requirement for the manufacturing and application of secretomes/EVs. However, as secretomes/EVs showed great promise as a therapeutic agent for SCI, secretome/EV treatment undoubtedly constitute a compelling approach for the treatment of SCI in the future.

\section{Immunotherapy}

A major challenge in spinal cord regeneration is the presence of growth-suppressive molecules which create a post-trauma milieu that impedes healing. Despite the complexity of the inhibitory interactions, investigations have shown that the application of immunotherapy in acute SCI model could modulate the molecular signaling pathway and modify the injury site microenvironment to favour regeneration $[90,91]$. Research conducted on a rodent SCI model indicated that antibodies targeting myelin-associated inhibitors could increase the locomotor function after injury [92]. Another study administered B-cell-depleting antibodies to control injury-associated inflammation and the treatment was found to subside the inflammation, promote cell survival and reduce hindlimb dysfunction [93]. Thus, the combination of immunotherapy and MSC treatment may be more effective in treating SCI by suppressing the inflammation and promoting cord regeneration. However, before these therapies can be used in patients, its safety must be clearly demonstrated by proving these antibodies do not affect healthy myelin and will not elicit detrimental immunological responses.

\section{Scaffolds}

Scaffolds and injectable hydrogels are being explored as a matrix to promote cell engraftment and cell survival during transplantation. The scaffolds and hydrogels can be made of natural, synthetic or combined materials [94]. Previously, it has been reported that MSCs seeded in the fibrin scaffold showed good viability up to 10 weeks upon transplantation using the rat SCI model [95, 96]. With the advancement in biomaterial research, researchers have developed scaffolds that not only retain the cells at the lesion site and support cell survival but also modulate the cell functionality by enhancing its capability to reduce fibrosis and inflammation as well as to promote angiogenesis and neurogenesis. Furthermore, the scaffold itself also has the function of inhibiting glial scar formation, subside inflammation, stimulate angiogenesis and promote neurogenesis [94, 97]. The systematic review and meta-analysis conducted by Yousefifard et al. [98] showed that combination of MSCs and scaffolds is more effective compared to MSCs and scaffolds alone in improving the motor function in animal SCI models.

A recent study that reported a phase I clinical trial on 40 patients with acute complete SCI found that the patients received collagen scaffold + UC-MSCs 
demonstrated improvement in ASIA grade, activities of daily living (ADL) score, bowel and bladder function, and MEP compared to those in the control group without UC-MSCs-loaded scaffold that showed no improvement after 12 months [99]. MRI of the treated patients showed nerve regeneration and the diffusion tensor imaging illustrated that the electrophysiological activity was recovered. Another study by Zhao et al. [36] demonstrated that treatment with NeuroRegen, a collagen scaffold, with umbilical cord blood-derived MSCs (UCBMSCs) in 8 patients with chronic complete SCI successfully enhanced the sensation level and increased the MEP-responsive area even though there was no change in ASIA grade. Results from these clinical studies clearly showed that scaffold can modulate the wound microenvironment to facilitate spinal cord regeneration.

Scaffolds have shown great promise in promoting regeneration of damaged spinal cord. However, several parameters, including biodegradation rate, biocompatibility, material safety and thickness of the matrix, need to be taken into consideration before clinical translation. In addition, issues such as product persistency and effectiveness also need to be resolved.

\section{Conclusion}

MSCs from multiple sources, i.e. bone marrow, adipose tissue and umbilical cord, have been used clinically to treat SCI. Many of these trials were conducted on patients with chronic SCI that have been paralyzed by the disease for years. Generally, MSC therapy is safe but unable to improve the neurological function of all treated patients. Nonetheless, it shed light on the SCI patients that have failed all other therapies by helping them to regain some sensory and motor function. Further studies are underway to improve the delivery of MSCs and MSCs-derived products via scaffolds or by combining with immunotherapy to improve the treatment efficacy.

\section{Acknowledgements}

Not applicable.

\section{Authors' contributions}

All the authors participate in drafting the article and revising it critically for important intellectual content. All authors read and approved the final manuscript.

\section{Funding}

This work was supported by research Grants (FF-2019-450/1 \& FF-2020-038) from Faculty of Medicine, Universiti Kebangsaan Malaysia.

\section{Availability of data and materials}

Not applicable.

Ethics approval and consent to participate

Not applicable.

Consent for publication

Not applicable.

\section{Competing interests}

The authors declare that they have no competing interests.

\section{Author details}

${ }^{1}$ Department of Physiology, Faculty of Medicine, Universiti Kebangsaan Malaysia Medical Centre, 56000 Kuala Lumpur, Malaysia. ${ }^{2}$ Ming Medical Services Sdn. Bhd., Pusat Perdagangan Dana 1, 47301 Petaling Jaya, Selangor, Malaysia. ${ }^{3}$ Centre for Tissue Engineering and Regenerative Medicine, Faculty of Medicine, Universiti Kebangsaan Malaysia Medical Centre, JalanYaacob Latif, Bandar Tun Razak, 56000 Kuala Lumpur, Malaysia.

Received: 13 May 2020 Accepted: 15 September 2020

Published online: 22 September 2020

\section{References}

1. Bradbury EJ, McMahon SB. Spinal cord repair strategies: why do they work? Nat Rev Neurosci. 2006;7(8):644.

2. Ahuja CS, Wilson JR, Nori S, Kotter MRN, Druschel C, Curt A, et al. Traumatic spinal cord injury. Nat Rev Dis Prim. 2017;3:17018.

3. Silva NA, Sousa N, Reis RL, Salgado AJ. From basics to clinical: a comprehensive review on spinal cord injury. Prog Neurobiol. 2014;114:25-57.

4. Tortora GJ, Derrickson BH. Principles of anatomy and physiology. Hoboken:Wiley; 2008.

5. Aziz I, Che Ramli MD, Zain M, Suraya N, Sanusi J. Behavioral and histopathological study of changes in spinal cord injured rats supplemented with Spirulina platensis. Evid Based Complement Altern Med. 2014;2014:871657.

6. Singh A, Tetreault L, Kalsi-Ryan S, Nouri A, Fehlings MG. Global prevalence and incidence of traumatic spinal cord injury. Clin Epidemiol. 2014;23(6):309-31.

7. Liu J, Han D, Wang Z, Xue M, Zhu L, Yan H, et al. Clinical analysis of the treatment of spinal cord injury with umbilical cord mesenchymal stem cells. Cytotherapy. 2013;15(2):185-91.

8. Silver J, Schwab ME, Popovich PG. Central nervous system regenerative failure: role of oligodendrocytes, astrocytes, and microglia. Cold Spring Harb Perspect Biol. 2015;7(3):a020602.

9. Nas K, Yazmalar L, Şah V, Aydın A, Öneş K. Rehabilitation of spinal cord injuries. World J Orthop. 2015;6(1):8-16.

10. Cheung V, Hoshide R, Bansal V, Kasper E, Chen CC. Methylprednisolone in the management of spinal cord injuries: lessons from randomized, controlled trials. Surg Neurol Int. 2015;6:142.

11. Trounson A, McDonald C. Stem cell therapies in clinical trials: progress and challenges. Cell Stem Cell. 2015;17(1):11-22.

12. Ruzicka J, Machova-Urdzikova L, Gillick J, Amemori T, Romanyuk N, Karova $K$, et al. A comparative study of three different types of stem cells for treatment of rat spinal cord injury. Cell Transplant. 2017;26(4):585-603.

13. Nori S, Ahuja CS, Fehlings MG. Translational advances in the management of acute spinal cord injury: what is new? What is hot? Neurosurgery. 2017;64(CN_suppl_1):119-28.

14. Lim J, Razi ZRM, Law J, Nawi AM, Idrus RBH, Ng MH. MSCs can be differentially isolated from maternal, middle and fetal segments of the human umbilical cord. Cytotherapy. 2016;18(12):1493-502.

15. Liau LL, Looi QH, Eng SP, Yazid MD, Sulaiman N, Busra MFM, et al. Mesenchymal stem cells for the treatment of immune-mediated diseases. In: Stem Cells. World Scientific; 2020. p. 178-210.

16. McDonald JW, Sadowsky C. Spinal-cord injury. Lancet. 2002;359(9304):417-25.

17. van Middendorp JJ, Hosman AJF, Pouw MH, Group ESS, van de Meent $\mathrm{H}$. Is determination between complete and incomplete traumatic spinal cord injury clinically relevant? Validation of the ASIA sacral sparing criteria in a prospective cohort of 432 patients. Spinal Cord. 2009;47(11):809-16.

18. Alizadeh A, Dyck SM, Karimi-Abdolrezaee S. Traumatic spinal cord injury: an overview of pathophysiology, models and acute injury mechanisms. Front Neurol. 2019;10:282.

19. Leal-Filho MB. Spinal cord injury: from inflammation to glial scar. Surg Neurol Int. 2011:2:112.

20. Yuan Y-M, He C. The glial scar in spinal cord injury and repair. Neurosci Bull. 2013;29(4):421-35. 
21. Orr MB, Gensel JC. Spinal cord injury scarring and inflammation: therapies targeting glial and inflammatory responses. Neurotherapeutics. 2018;15(3):541-53.

22. Hulsebosch CE. Recent advances in pathophysiology and treatment of spinal cord injury. Adv Physiol Educ. 2002;26(4):238-55.

23. Bonner S, Smith C. Initial management of acute spinal cord injury. Contin Educ Anaesthesia Crit Care Pain. 2013;13(6):224-31.

24. Rabinstein AA. Traumatic spinal cord injury. Contin Lifelong Learn Neurol. 2018;24(2, Spinal Cord Disorders):551-66.

25. Kirshblum SC, Burns SP, Biering-Sorensen F, Donovan W, Graves DE, Jha A, et al. International standards for neurological classification of spinal cord injury (Revised 2011). J Spinal Cord Med. 2011;34(6):535-46.

26. Sanchez-Ramos J, Song S, Cardozo-Pelaez F, Hazzi C, Stedeford T, Willing A, et al. Adult bone marrow stromal cells differentiate into neural cells in vitro. Exp Neurol. 2000;164(2):247-56.

27. Qi X, Shao M, Peng H, Bi Z, Su Z, Li H. In vitro differentiation of bone marrow stromal cells into neurons and glial cells and differential protein expression in a two-compartment bone marrow stromal cell/neuron co-culture system. J Clin Neurosci. 2010;17(7):908-13.

28. Lim WL, Liau LL, Ng MH, Shiplu RC, Law JX. Current progress in tendon and ligament tissue engineering. Tissue Eng Regen Med. 2019;16:549-71.

29. Rehman J, Traktuev D, Li J, Merfeld-Clauss S, Temm-Grove CJ, Bovenkerk $J E$, et al. Secretion of angiogenic and antiapoptotic factors by human adipose stromal cells. Circulation. 2004;109(10):1292-8.

30. Uccelli A, Moretta L, Pistoia V. Mesenchymal stem cells in health and disease. Nat Rev Immunol. 2008;8(9):726.

31. Sorrell JM, Baber MA, Caplan Al. Influence of adult mesenchymal stem cells on in vitro vascular formation. Tissue Eng Part A. 2009;15(7):1751-61.

32. Hofer HR, Tuan RS. Secreted trophic factors of mesenchymal stem cells support neurovascular and musculoskeletal therapies. Stem Cell Res Ther. 2016;7(1):131.

33. Weiss ML, Anderson C, Medicetty S, Seshareddy KB, Weiss RJ, VanderWerff I, et al. Immune properties of human umbilical cord Wharton's jellyderived cells. Stem Cells. 2008;26(11):2865-74.

34. Avanzini MA, Bernardo ME, Cometa AM, Perotti C, Zaffaroni N, Novara $F$, et al. Generation of mesenchymal stromal cells in the presence of platelet lysate: a phenotypic and functional comparison of umbilical cord blood-and bone marrow-derived progenitors. Haematologica. 2009;94(12):1649-60.

35. Lim J, Razi ZRM, Law JX, Nawi AM, Idrus RBH, Chin TG, et al. Mesenchymal stromal cells from the maternal segment of human umbilical cord is ideal for bone regeneration in allogenic setting. Tissue Eng Regen Med. 2018;15(1):75-87.

36. Zhao Y, Tang F, Xiao Z, Han G, Wang N, Yin N, et al. Clinical study of NeuroRegen scaffold combined with human mesenchymal stem cells for the repair of chronic complete spinal cord injury. Cell Transplant. 2017;26(5):891-900.

37. Kemp K, Mallam E, Hares K, Witherick J, Scolding N, Wilkins A. Mesenchymal stem cells restore frataxin expression and increase hydrogen peroxide scavenging enzymes in Friedreich ataxia fibroblasts. PLOS ONE. 2011;6(10):e26098.

38. da Costa Gonçalves F, Grings M, Nunes NS, Pinto FO, Garcez TNA, Visioli F, et al. Antioxidant properties of mesenchymal stem cells against oxidative stress in a murine model of colitis. Biotechnol Lett. 2017;39(4):613-22.

39. Hafez P, Chowdhury SR, Jose S, Law JX, Ruszymah BHI, Ramzisham ARM, et al. Development of an in vitro cardiac ischemic model using primary human cardiomyocytes. Cardiovasc Eng Technol. 2018;9(3):529-38.

40. Jeon SR, Park JH, Lee JH, Kim DY, Kim HS, Sung IY, et al. Treatment of spinal cord injury with bone marrow-derived, cultured autologous mesenchymal stem cells. Tissue Eng Regen Med. 2010;7(3):316-22.

41. Park JH, Kim DY, Sung IY, Choi GH, Jeon MH, Kim KK, et al. Longterm results of spinal cord injury therapy using mesenchymal stem cells derived from bone marrow in humans. Neurosurgery. 2011;70(5):1238-47

42. Oh SK, Choi KH, Yoo JY, Kim DY, Kim SJ, Jeon SR. A phase III clinical trial showing limited efficacy of autologous mesenchymal stem cell therapy for spinal cord injury. Neurosurgery. 2016;78(3):436-47.

43. Saito F, Nakatani T, Iwase M, Maeda Y, Murao Y, Suzuki Y, et al. Administration of cultured autologous bone marrow stromal cells into cerebrospinal fluid in spinal injury patients: a pilot study. Restor Neurol Neurosci. 2012:30(2):127-36.
44. El-Kheir WA, Gabr H, Awad MR, Ghannam O, Barakat Y, Farghali HAMA et al. Autologous bone marrow-derived cell therapy combined with physical therapy induces functional improvement in chronic spinal cord injury patients. Cell Transplant. 2014;23(6):729-45.

45. Karamouzian S, Nematollahi-Mahani SN, Nakhaee N, Eskandary H. Clinical safety and primary efficacy of bone marrow mesenchymal cell transplantation in subacute spinal cord injured patients. Clin Neurol Neurosurg. 2012;114(7):935-9.

46. Pal R, Venkataramana NK, Bansal A, Balaraju S, Jan M, Chandra R, et al. Ex vivo-expanded autologous bone marrow-derived mesenchymal stromal cells in human spinal cord injury/paraplegia: a pilot clinical study. Cytotherapy. 2009;11(7):897-911.

47. Vaquero J, Zurita M, Rico MA, Aguayo C, Bonilla C, Marin E, et al. Intrathecal administration of autologous mesenchymal stromal cells for spinal cord injury: safety and efficacy of the 100/3 guideline. Cytotherapy. 2018;20(6):806-19.

48. Mendonça MVP, Larocca TF, de Freitas Souza BS, Villarreal CF, Silva LFM, Matos AC, et al. Safety and neurological assessments after autologous transplantation of bone marrow mesenchymal stem cells in subjects with chronic spinal cord injury. Stem Cell Res Ther. 2014;5(6):126.

49. Dai G, Liu X, Zhang Z, Yang Z, Dai Y, Xu R. Transplantation of autologous bone marrow mesenchymal stem cells in the treatment of complete and chronic cervical spinal cord injury. Brain Res. 2013;1533:73-9.

50. Jiang P-C, Xiong W-P, Wang G, Ma C, Yao W-Q, Kendell SF, et al. A clinical trial report of autologous bone marrow-derived mesenchymal stem cell transplantation in patients with spinal cord injury. Exp Ther Med. 2013;6(1):140-6.

51. Syková E, Homola A, Mazanec R, Lachmann H, Langkramer Konrádová Š, Kobylka P, et al. Autologous bone marrow transplantation in patients with subacute and chronic spinal cord injury. Cell Transplant. 2006;15(8-9):675-87.

52. Geffner LF, Santacruz P, Izurieta M, Flor L, Maldonado B, Auad AH, et al. Administration of autologous bone marrow stem cells into spinal cord injury patients via multiple routes is safe and improves their quality of life: comprehensive case studies. Cell Transplant. 2008;17(12):1277-93.

53. Jarocha D, Milczarek O, Wedrychowicz A, Kwiatkowski S, Majka M. Continuous improvement after multiple mesenchymal stem cell transplantations in a patient with complete spinal cord injury. Cell Transplant. 2015;24(4):661-72.

54. Sharma A, Sane H, Gokulchandran N, Kulkarni P, Thomas N, Bhovad P. Role of autologous bone marrow mononuclear cells in chronic cervical spinal cord injury - a longterm follow up study. J Neurol Disord. 2013;1(138):2.

55. Liau LL, Ruszymah BHI, Ng MH, Law JX. Characteristics and clinical applications of Wharton's jelly-derived mesenchymal stromal cells. Curr Res Transl Med. 2020;68(1):5-16.

56. de Girolamo L, Lucarelli E, Alessandri G, Antonietta Avanzini M, Ester

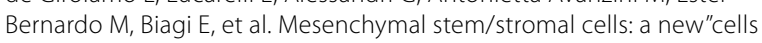
as drugs"paradigm. Efficacy and critical aspects in cell therapy. Curr Pharm Des. 2013;19(13):2459-73.

57. Kim D-W, Staples M, Shinozuka K, Pantcheva P, Kang S-D, Borlongan CV. Wharton's jelly-derived mesenchymal stem cells: phenotypic characterization and optimizing their therapeutic potential for clinical applications. Int J Mol Sci. 2013;14(6):11692-712.

58. Nagamura-Inoue T, He H. Umbilical cord-derived mesenchymal stem cells: their advantages and potential clinical utility. World J Stem Cells. 2014:6(2):195.

59. Sabapathy V, Sundaram B, Sreelakshmi VM, Mankuzhy P, Kumar S. Human Wharton's jelly mesenchymal stem cells plasticity augments scar-free skin wound healing with hair growth. PLOS ONE. 2014;9(4):e93726.

60. Barry FP, Murphy JM, English K, Mahon BP. Immunogenicity of adult mesenchymal stem cells: lessons from the fetal allograft. Stem Cells Dev. 2005; 14(3):252-65.

61. Cheng H, Liu X, Hua R, Dai G, Wang X, Gao J, et al. Clinical observation of umbilical cord mesenchymal stem cell transplantation in treatment for sequelae of thoracolumbar spinal cord injury. J Transl Med. 2014;12(1):253.

62. De Ugarte DA, Morizono K, Elbarbary A, Alfonso Z, Zuk PA, Zhu M, et al. Comparison of multi-lineage cells from human adipose tissue and bone marrow. Cells Tissues Organs. 2003;174(3):101-9. 
63. Zuk PA, Zhu M, Mizuno H, Huang J, Futrell JW, Katz AJ, et al. Multilineage cells from human adipose tissue: implications for cell-based therapies. In: Tissue Engineering. United States; 2001. p. 211-28.

64. Hur JW, Cho TH, Park DH, Lee JB, Park JY, Chung YG. Intrathecal transplantation of autologous adipose-derived mesenchymal stem cells for treating spinal cord injury: a human trial. J Spinal Cord Med. 2016;39(6):655-64.

65. Bydon M, Dietz AB, Goncalves S, Moinuddin FM, Alvi MA, Goyal A, et al. CELLTOP clinical trial: first report from a phase 1 trial of autologous adipose tissue-derived mesenchymal stem cells in the treatment of paralysis due to traumatic spinal cord injury. Mayo Clin Proc. 2020;95(2):406-14.

66. Lam H, Tran M, Bui K, Le T, Bui K, Phan N, et al. Adipose tissue derived stromal vascular fraction transplantation can recover spinal cord injury in mice. Prog Stem Cell. 2016:3(04):144-58.

67. Jung DI, Ha J, Kang BT, Kim JW, Quan FS, Lee JH, et al. A comparison of autologous and allogenic bone marrow-derived mesenchymal stem cell transplantation in canine spinal cord injury. J Neurol Sci. 2009;285(1):67-77.

68. Takahashi A, Nakajima H, Uchida K, Takeura N, Honjoh K, Watanabe S, et al. Comparison of mesenchymal stromal cells isolated from murine adipose tissue and bone marrow in the treatment of spinal cord injury. Cell Transplant. 2018;27(7):1126-39.

69. Cofano F, Boido M, Monticelli M, Zenga F, Ducati A, Vercelli A, et al. Mesenchymal stem cells for spinal cord injury: current options limitations, and future of cell therapy. Int J Mol Sci. 2019;20(11):2698.

70. Qu J, Zhang H. Roles of mesenchymal stem cells in spinal cord injury. Stem Cells Int. 2017:2017:5251313.

71. Shao A, Tu S, Lu J, Zhang J. Crosstalk between stem cell and spinal cord injury: pathophysiology and treatment strategies. Stem Cell Res Ther. 2019;10(1):238

72. Mothe AJ, Tator $\mathrm{CH}$. Advances in stem cell therapy for spinal cord injury. J Clin Invest. 2012;122(11):3824-34.

73. Stastna M, Van Eyk JE. Investigating the secretome: lessons about the cells that comprise the heart. Circ Cardiovasc Genet. 2012;5(1):08-18.

74. Huang JH, Yin XM, Xu Y, Xu CC, Lin X, Ye FB, et al. Systemic administration of exosomes released from mesenchymal stromal cells attenuates apoptosis, inflammation, and promotes angiogenesis after spinal cord injury in rats. J Neurotrauma. 2017:34(24):3388-96.

75. Ha D, Yang N, Nadithe V. Exosomes as therapeutic drug carriers and delivery vehicles across biological membranes: current perspectives and future challenges. Acta Pharm Sinica B. 2016;6(4):287-96.

76. Sarko DK, McKinney CE. Exosomes: origins and therapeutic potential for neurodegenerative disease. Front Neurosci. 2017;11:82.

77. Martins LF, Costa RO, Pedro JR, Aguiar P, Serra SC, Teixeira FG, et al. Mesenchymal stem cells secretome-induced axonal outgrowth is mediated by BDNF. Sci Rep. 2017;7(1):4153.

78. Zhou X, Chu X, Yuan H, Qiu J, Zhao C, Xin D, et al. Mesenchymal stem cell derived EVs mediate neuroprotection after spinal cord injury in rats via the microRNA-21-5p/FasL gene axis. Biomed Pharmacother. 2019;115:108818.

79. Guo S, Perets N, Betzer O, Ben-Shaul S, Sheinin A, Michaelevski I, et al. Intranasal delivery of mesenchymal stem cell derived exosomes loaded with phosphatase and tensin homolog siRNA repairs complete spinal cord injury. ACS Nano. 2019;13(9):10015-28.

80. Liu W, Wang Y, Gong F, Rong Y, Luo Y, Tang P, et al. Exosomes derived from bone mesenchymal stem cells repair traumatic spinal cord injury by suppressing the activation of a1 neurotoxic reactive astrocytes. J Neurotrauma. 2019;36(3):469-84.

81. Lu Y, Zhou Y, Zhang R, Wen L, Wu K, Li Y, et al. Bone mesenchymal stem cell-derived extracellular vesicles promote recovery following spinal cord injury via improvement of the integrity of the blood-spinal cord barrier. Front Neurosci. 2019;13:209.

82. Ren ZW, Zhou JG, Xiong ZK, Zhu FZ, Guo XD. Effect of exosomes derived from MiR-133b-modified ADSCs on the recovery of neurological function after SCI. Eur Rev Med Pharmacol Sci. 2019;23(1):52-60.
83. Liu S, Jia Y, Yuan M, Guo W, Huang J, Zhao B, et al. Repair of osteochondral defects using human umbilical cord Wharton's jelly-derived mesenchymal stem cells in a rabbit model. Biomed Res Int. 2017;2017:8760383.

84. Wang L, Pei S, Han L, Guo B, Li Y, Duan R, et al. Mesenchymal stem cell-derived exosomes reduce $\mathrm{A} 1$ astrocytes via downregulation of phosphorylated NFkB P65 subunit in spinal cord injury. Cell Physiol Biochem. 2018;50(4):1535-59.

85. Shiue SJ, Rau RH, Shiue HS, Hung YW, Li ZX, Yang KD, et al. Mesenchymal stem cell exosomes as a cell-free therapy for nerve injury-induced pain in rats. Pain. 2019;160(1):210-23.

86. Lu XC, Zheng JY, Tang LJ, Huang BS, Li K, Tao Y, et al. MiR-133b promotes neurite outgrowth by targeting RhoA expression. Cell Physiol Biochem. 2015;35(1):246-58.

87. Li D, Zhang P, Yao X, Li H, Shen H, Li X, et al. Exosomes derived from miR$133 \mathrm{~b}$-modified mesenchymal stem cells promote recovery after spinal cord injury. Front Neurosci. 2018;12:845.

88. Liu W, Rong Y, Wang J, Zhou Z, Ge X, Ji C, et al. Exosome-shuttled miR215a-5p from hypoxic preconditioned mesenchymal stem cells repair traumatic spinal cord injury by shifting microglial M1/M2 polarization. J Neuroinflamm. 2020;17:47.

89. Yu T, Zhao C, Hou S, Zhou W, Wang B, Chen Y. Exosomes secreted from miRNA-29b-modified mesenchymal stem cells repaired spinal cord injury in rats. Braz J Med Biol Res. 2019;52(12):e8735.

90. Bregman BS, Kunkel-Bagden E, Schnell L, Dai HN, Gao D, Schwab ME. Recovery from spinal cord injury mediated by antibodies to neurite growth inhibitors. Nature. 1995;378(6556):498-501.

91. Lee JK, Zheng B. Role of myelin-associated inhibitors in axonal repair after spinal cord injury. Exp Neurol. 2012;235(1):33-42

92. Liebscher T, Schnell L, Schnell D, Scholl J, Schneider R, Gullo M, et al. Nogo-A antibody improves regeneration and locomotion of spinal cordinjured rats. Ann Neurol. 2005;58(5):706-19.

93. Casili G, Impellizzeri D, Cordaro M, Esposito E, Cuzzocrea S. B-cell depletion with CD20 antibodies as new approach in the treatment of inflammatory and immunological events associated with spinal cord injury. Neurotherapeutics. 2016:13(4):880-94.

94. Liu S, Xie Y-Y, Wang B. Role and prospects of regenerative biomaterials in the repair of spinal cord injury. Neural Regen Res. 2019;14(8):1352-63.

95. Mukhamedshina YO, Zakirova EY, Galieva LR, Kostennikov AA, Akhmetzyanova ER, Rizvanov AA. Distribution and survival of transplanted adiposederived mesenchymal stem cells in the spinal cord injury. Bionanoscience. 2017;7(4):608-12.

96. Sabino L, Maria CA, Luca L, Valerio V, Edda F, Giacomo R, et al. Engraftment, neuroglial transdifferentiation and behavioral recovery after complete spinal cord transection in rats. Surg Neurol Int. 2018;9:19.

97. Higuchi A, Suresh Kumar S, Benelli G, Ling Q-D, Li H-F, Alarfaj AA, et al. Biomaterials used in stem cell therapy for spinal cord injury. Prog Mater Sci. 2019;103:374-424.

98. Yousefifard M, Maleki SN, Askarian-Amiri S, Vaccaro AR, Chapman JR, Fehlings $M G$, et al. A combination of mesenchymal stem cells and scaffolds promotes motor functional recovery in spinal cord injury: a systematic review and meta-analysis. J Neurosurg Spine. 2019:32(2):269-84.

99. Deng W-S, Ma K, Liang B, Liu X-Y, Xu H-Y, Zhang J, et al. Collagen scaffold combined with human umbilical cord-mesenchymal stem cells transplantation for acute complete spinal cord injury. Neural Regen Res. 2020;15(9):1686-700.

\section{Publisher's Note}

Springer Nature remains neutral with regard to jurisdictional claims in published maps and institutional affiliations. 